\title{
Endomyocardial Fibrosis Secondary to Hypereosinophilic Syndrome
}

Pablo Merás*, Nieves Montoro, Verónica Rial, Javier Irazusta, Ángel Iniesta, Óscar González, Elena Refoyo, Ángel Robles, Mar Moreno and José Luis López-Sendón

Hospital Universitario La Paz, Spain

Submission: May 28, 2017; Published: June 30, 2017

*Corresponding author: Pablo Merás, Hospital Universitario La Paz, Madrid, Tel: 654277645; Email: merascolunga@gmail.com

Abstract

We present the case of a 27-year-old man with a complex peripheal vascular disease who developed a progressive heart failure with systolic ventricular dysfunction and severe mitral regurgitation with a restrictive diastolic pattern. The complementary tests and a wide differential diagnosis will be the main points of the case, leading to an uncommon diagnosis. A global and multidisciplinary approach is a key factor when facing these kind of patients.

Keywords: Endomyocardial fibrosis; Hypereosinophilic syndrome; Myocarditis; Heart failure; Magnetic resonance imaging

\section{Case Report}

We present the case of a 27-year-old man from Paraguay, without cardiovascular risk factors or previous cardiac disease, referred to our centre because of pain, paresthesias and ulcered lesions in both lower limbs. Four years ago, he had had

Table 1: Laboratory data at admission.

\begin{tabular}{|c|c|c|c|c|c|c|}
\hline Haemoglobin & MCV & Leucocytes & Neutrophiles & Eosinophiles & Lymphocytes & Platelets \\
\hline $7,5 \mathrm{~g} / \mathrm{dl}$ & $63 \mathrm{fL}$ & $14100 / \mathrm{mcL}$ & $10800 / \mathrm{mcL}$ & $10,4 \% / 1500 \mathrm{mcl}$ & $2229 / \mathrm{mcL}$ & $776000 / \mathrm{mcL}$ \\
\hline Creatinine & Sodium & Potassium & ESR & CRP & IgE & $\begin{array}{c}\text { Eosinophil } \\
\text { cationic protein }\end{array}$ \\
\hline $0.83 \mathrm{mg} / \mathrm{dL}$ & $140 \mathrm{mEq} / \mathrm{L}$ & $4,2 \mathrm{mEq} / \mathrm{L}$ & 46 & 81 & $622 \mathrm{kU} / \mathrm{L}$ & $167,9 \mathrm{mcg} / \mathrm{L}$ \\
\hline $\mathrm{Fe}$ & Ferritin & $\begin{array}{c}\text { Transferrin } \\
\text { saturation } 8 \%\end{array}$ & INR & & & \\
\hline $32 \mathrm{mcg} / \mathrm{dl}$ & $457 \mathrm{ng} / \mathrm{ml}$ & & 1,1 & & \\
\hline
\end{tabular}

Laboratory findings at admission are shown in Table 1. He had high blood levels of eosinophyles and IgE, anaemia and mild erythrocyte sedimentation rate (ESR) elevation. A complete microbiological study was made with negative results, and the same occurred with the coagulation tests and the immunological study except for positivity of endomysial and transglutaminase antibodies. a previous hospital admission in another institution due to anaemia, bilateral lung infiltrates and elevated eosinophiles and IgE. However, the patient was not taking any medication nor was under clinical follow-up.
A bilateral limb arteriogram was performed (Figure 1). It showed diffuse arterial disease with areas of stenosis and occlusion as well as important collateral circulation. Given these findings, the patient was diagnosed with advanced lower extremity peripheral artery disease and, despite medical treatment, he finally required a left limb supracondylar amputation. The histological findings revealed partial arterial 
occlusion by thrombosis, fibrosis areas and inflammatory infiltrates of lymphocites and neutrophiles.
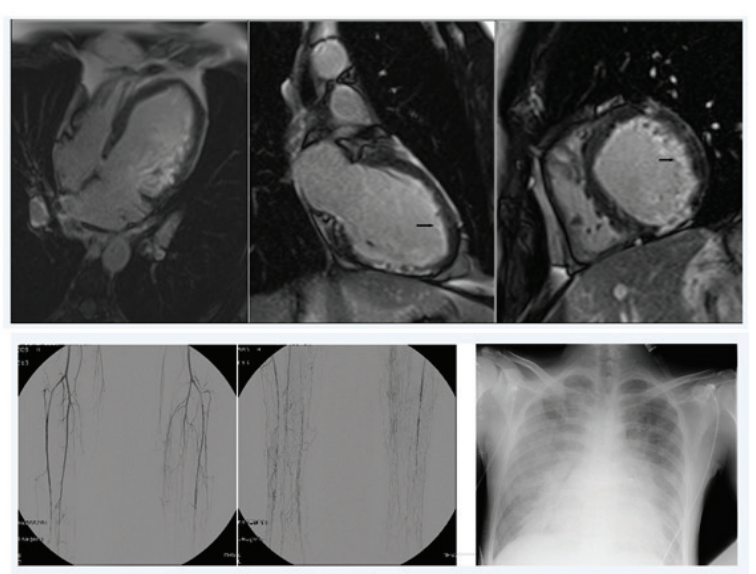

Figure 1: Images of the perforating lead: (1a) CX-ray showing perforating lead extending outside the pericardium reaching down to under the diaphragm.

During the postoperative period, he suffered an acute pulmonary edema requiring surveillance in the intensive care unit. Chest radiography is shown in Figure 2. The ECG showed sinus tachycardia with left bundle branch block. In addition, an echocardiogram was performed, revealing severe left ventricular dysfunction with global hypokinesia and a diastolic restrictive pattern, secondary severe mitral regurgitation and mild right ventricular dysfunction. Treatment with intravenous diuretics and non invasive mechanical ventilation was initiated and, after a few days, he was discharged from the ICU to a medicine ward.

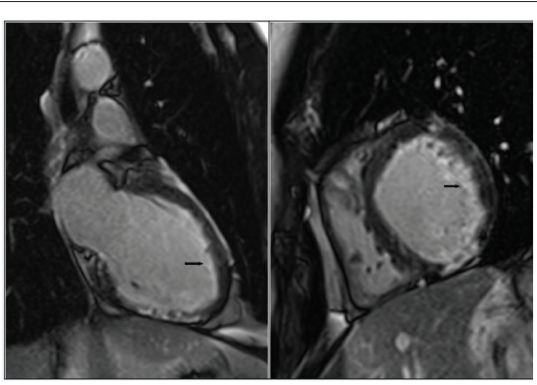

Figure 2: CMR showing subendocardial late gadolinium enhancement.

The cardiologic study was completed with a cardiac magnetic resonance (CMR) that revealed circumferential subendocardial late gadolinium enhancement in both ventricles compatible with endomyocardial fibrosis, without areas of edema in STIR sequences. Coronary artery disease was ruled out with an angio-CT. Finally, an endomyocardial biopsy was made, which unfortunately was not conclusive.

Due to the hematological abnormalities, a bone marrow biopsy was performed that showed a reactive myelogram without clonal proliferation. In addition, an abdominal fat pad biopsy was negative for Congo red.

\section{Discussion}

In short, this is a complex case with multisystemic implication, the cardiac and vascular disease being outstanding, but also with pulmonary and hematologic involvement. Main objective findings that guided us for diferential diagnosis were: hypereosinophily, peripheral artery disease and endomyocardial fibrosis.

Table 2: Differential diagnosis.

\begin{tabular}{|c|c|c|}
\hline Etiology & $\begin{array}{l}\text { Favors the } \\
\text { Diagnosis }\end{array}$ & $\begin{array}{l}\text { Against the } \\
\text { Diagnosis }\end{array}$ \\
\hline $\begin{array}{l}\text { Coronary artery } \\
\text { disease }\end{array}$ & $\begin{array}{c}\text { Peripheral artery } \\
\text { disease }\end{array}$ & Angio-CT \\
\hline $\begin{array}{c}\text { Infiltrative } \\
\text { cardiomyopathy: } \\
\text {-Amyloidosis } \\
\text {-Hemochromatosis }\end{array}$ & Restrictive pattern & $\begin{array}{l}\text { Negative Congo red } \\
\text { No iron overload }\end{array}$ \\
\hline $\begin{array}{l}\text { Granulomatous } \\
\text { disease: } \\
\text {-Sarcoidosis } \\
\text {-Churg-Strauss }\end{array}$ & $\begin{array}{l}\text { Multisystemic } \\
\text { involvement }\end{array}$ & $\begin{array}{c}\text { No CRM suggestive, } \\
\text { no granulomes in } \\
\text { biopsy }\end{array}$ \\
\hline Autoimmune disease & $\begin{array}{l}\text { Multisystemic } \\
\text { involvement }\end{array}$ & Negative antibodies \\
\hline $\begin{array}{l}\text { Infectious causes: } \\
\text { HIV, Lyme, Chagas... }\end{array}$ & $\begin{array}{c}\text { Natural from } \\
\text { Paraguay (Chagas) }\end{array}$ & Negative blood tests \\
\hline $\begin{array}{l}\text { Toxins: ethanol, } \\
\text { cocaine, } \\
\text { chemotherapy }\end{array}$ & $\begin{array}{l}\text { May cause DCM and } \\
\text { affect other organs }\end{array}$ & No patient intake \\
\hline $\begin{array}{l}\text { Endocrinal disease, } \\
\text { nutritional deficits }\end{array}$ & May cause DCM & Not found \\
\hline $\begin{array}{l}\text { Myocarditis: } \\
\text { virus, giant-cell, } \\
\text { hypersensitivity, } \\
\text { necrotizing } \\
\text { eosinophilic } \\
\text { myocarditis... }\end{array}$ & $\begin{array}{c}\text { Ventricular } \\
\text { dysfunction and } \\
\text { heart failure in young } \\
\text { patients. }\end{array}$ & $\begin{array}{l}\text { Do not fit with the } \\
\text { clinical presentation }\end{array}$ \\
\hline Celiac disease & $\begin{array}{l}\text { Possible cause } \\
\text { of dilated } \\
\text { cardiomyopathy } \\
\text { and pulmonary } \\
\text { hemosiderosis. } \\
\text { Positive antibodies }\end{array}$ & $\begin{array}{c}\text { No improvement } \\
\text { after } \\
\text { immunosuppressors } \\
\text { and gluten-free } \\
\text { diet. No digestive } \\
\text { symptoms }\end{array}$ \\
\hline Buerger disease & $\begin{array}{l}\text { Anatomo- } \\
\text { pathological results } \\
\text { from lower limb }\end{array}$ & $\begin{array}{l}\text { No smoking history. } \\
\text { Does not involve } \\
\text { other organs }\end{array}$ \\
\hline $\begin{array}{c}\text { Primary } \\
\text { cardiomyopathies }\end{array}$ & Young adult & No family history \\
\hline
\end{tabular}




\begin{tabular}{|c|c|c|}
\hline $\begin{array}{c}\text { Elevated } \\
\text { Hypereosinophilic } \\
\text { syndrome }\end{array}$ & $\begin{array}{c}\text { posinophiles, IgE, } \\
\text { eosinophil cationic } \\
\text { protein. Explains } \\
\text { multisystemic } \\
\text { involvement (heart, } \\
\text { peripheral vessels, } \\
\text { lungs...). Primary and } \\
\text { secondary causes } \\
\text { were excluded }\end{array}$ & $\begin{array}{c}\text { No confirmation } \\
\text { on endomyocardial } \\
\text { biopsy }\end{array}$ \\
\hline $\begin{array}{c}\text { Endomyocardial } \\
\text { fibrosis }\end{array}$ & $\begin{array}{c}\text { CRM suggestive. } \\
\text { Possible end stage } \\
\text { of HES }\end{array}$ & $\begin{array}{c}\text { No confirmation } \\
\text { on endomyocardial } \\
\text { biopsy }\end{array}$ \\
\hline
\end{tabular}

We considered a wide differential diagnosis (Table 2). First of all, we ruled out infectious diseases, mainly parasitic infections (common cause of eosinophiles and IgE elevation), but also HIV, Lyme and Chagas disease, among others. The patient had positive celiac disease antibodies. There are some previous studies [1] that suggest that celiac disease accounts for as many as 5 percent of patients with autoimmune myocarditis or idiopathic dilated cardiomyopathy, sometimes with any classic gastrointestinal symptoms of celiac disease (recurrent abdominal pain, diarrhea and weight loss), but all cases had iron deficiency anemia refractory to oral iron replacement. Cardiac function improved following a gluten-free diet with or without immunosuppressive therapy. Our patient did not experience left ventricular function recovery in spite of the fact he was placed on high doses of corticosteroids and he followed a gluten-free diet. Other endocrinal disease or nutritional deficits may cause dilated cardiomyopathy (DCM) but were not found in our patient. Anatomopathological findings of lower limb were suggestive of Buerger disease. Nevertheless, the patient had never smoked, and, moreover, this disease does not involve other organs.

CMR was not suggestive of other etiologies: sarcoidosis (different pattern with typical intramyocardial enhancement, no granulomes in biopsies); or acute myocarditis such as viral, giant-cell, hypersensitivity, necrotizing eosinophilic myocarditis (absence of edema in STIR sequences).

Other systemic diseases such as amyloidosis (negative Congo red), hemochromatosis (no iron overload) or hypereosinophilic vasculitis (negative pANCA antibodies, no renal involvement), and toxins were also dismissed.

Hypereosinophilic syndrome (HES) [2-4] is a multisystemic disease as a result of maintained blood elevation of eosinophiles and IgE. Primary causes (hematologic disease) were dismissed by means of a bone marrow biopsy, as well as secondary causes (hypersensitivity, atopia, parasite infection, autoimmune disease, collagen disease, malignancy, eosinophilic pulmonary diseases, hyper-IgE syndrome, etc.). Thus it could be an idiopathic form.

About $5 \%$ of patients may have cardiac signs and symptoms at presentation, and eosinophilic myocarditis is a major cause of morbitity and mortality among patients with HES. Eosinophilmediated heart damage evolves through three stages: an acute necrosis stage; an intermediate phase characterized by thrombus formation along the damaged endocardium; and a final fibrotic stage. Patients often develop cardiopulmonary symptoms in the advanced stages. In the third, fibrotic stage, progressive scarring causes endomyocardial fibrosis, producing a restrictive cardiomyopathy and/or mitral or tricuspid valve regurgitation due to entrapment of the chordae tendineae. Peripheral artery disease may also be present in HES. Patients have been reported to develop femoral artery occlusion, intracranial sinus thrombosis, or digital gangrene.

Thus we believe that our patient suffered an idiopathic HES with important vascular and cardiac involvement, probably in an advanced phase, given the absence of edema and eosinophilic infiltration, and predominating fibrosis.

We initiated treatment with bisoprolol, enalapril, eplerenone and ivabradine. In addition, a CRT-D was implanted for primary prevention of sudden cardiac death. We also started corticosteroids and, later on, azathioprine, with analytical improvement but with no impact on left ventricular ejection fraction. Currently, the patient is in a stable situation, with good functional class, and no hospital readmissions.

Our learning from this patient was the importance of putting together all the results from a wide range of tests. This approach needs the collaboration among different specialities and departments (internal medicine, cardiac image, clinical cardiologists, vascular surgeons, hematologists, etc.) to ensure a correct diagnosis and management of these patients with complex multisystemic diseases.

\section{References}

1. Frustaci A, Cuoco L, Chimenti C, Pieroni M, Fioravanti G, et al. (2002) Celiac disease associated with autoimmune myocarditis. Circulation 105(22): 2611-2618.

2. Weller PF, Bubley GJ (1994) The idiopathic hypereosinophilic syndrome. Blood 83(10): 2759-2779.

3. Klion AD, Bochner BS, Gleich GJ, Nutman TB, Rothenberg ME, et al. (2006) Approaches to the treatment of hypereosinophilic syndromes: a workshop summary report. J Allergy Clin Immunol 117(6): 12921302.

4. Sheikh J, Weller PF (2007) Clinical overview of hypereosinophilic syndromes. Immunol Allergy Clin North Am 27(3): 333-355. 
This work is licensed under Creative Commons Attribution 4.0 License

DOI:-10.19080/JOCCT.2017.06.555683
Your next submission with Juniper Publishers will reach you the below assets

- Quality Editorial service

- Swift Peer Review

- Reprints availability

- E-prints Service

- Manuscript Podcast for convenient understanding

- Global attainment for your research

- Manuscript accessibility in different formats

( Pdf, E-pub, Full Text, Audio)

- Unceasing customer service

Track the below URL for one-step submission https://juniperpublishers.com/online-submission.php 